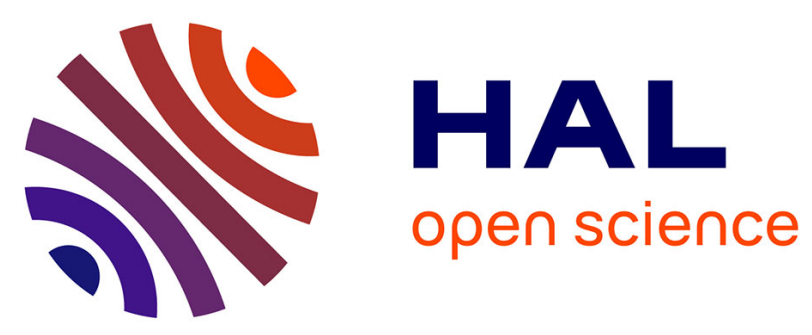

\title{
Mechanical behavior of a Ti-6Al-4 V titanium alloy with microstructural evolution modeling under hot and superplastic conditions
}

\author{
Marcio Wagner Batista dos Santos, Vincent Velay, Vanessa Vidal, Gérard \\ Bernhart, Gilmar Ferreira Batalha, Hiroaki Matsumoto
}

\section{To cite this version:}

Marcio Wagner Batista dos Santos, Vincent Velay, Vanessa Vidal, Gérard Bernhart, Gilmar Ferreira Batalha, et al.. Mechanical behavior of a Ti-6Al-4 V titanium alloy with microstructural evolution modeling under hot and superplastic conditions. Materials Science and Engineering Technology / Materialwissenschaft und Werkstofftechnik, 2017, Special Issue: 11th European Conference on Superplastic Forming (EuroSPF) (Selected contributions), 48 (10), p.952-961. 10.1002/mawe.201700040 . hal-01622051

\section{HAL Id: hal-01622051 https://imt-mines-albi.hal.science/hal-01622051}

Submitted on 6 Nov 2018

HAL is a multi-disciplinary open access archive for the deposit and dissemination of scientific research documents, whether they are published or not. The documents may come from teaching and research institutions in France or abroad, or from public or private research centers.
L'archive ouverte pluridisciplinaire HAL, est destinée au dépôt et à la diffusion de documents scientifiques de niveau recherche, publiés ou non, émanant des établissements d'enseignement et de recherche français ou étrangers, des laboratoires publics ou privés. 


\title{
Mechanical behavior of a Ti-6Al-4 V titanium alloy with microstructural evolution modeling under hot and superplastic conditions
}

\section{Mechanisches Verhalten einer Ti-6Al-4 V-Titanlegierung mit mikrostruktureller Evolutionsmodellierung unter warmen und superplastischen Bedingungen.}

\author{
M. W. dos Santos ${ }^{1}$, V. Velay ${ }^{2}$, V. Vidal ${ }^{2}$, G. Bernhart ${ }^{2}$, G. F. Batalha ${ }^{1}$, \\ H. Matsumoto ${ }^{3}$
}

\begin{abstract}
The present work aims at evaluating and understanding the mechanical behavior of a Ti-6Al-4 V alloy under hot and superplastic forming conditions. Tensile tests were performed at temperature range from $650^{\circ} \mathrm{C}$ to $950^{\circ} \mathrm{C}$, at strain rates between $10^{-2} \mathrm{~s}^{-1}$ and $10^{-4} \mathrm{~s}^{-1}$. Three equiaxed microstructures, each characterized by a different starting grain size $(4.9 \mu \mathrm{m}, 3.0 \mu \mathrm{m}$ and $0.5 \mu \mathrm{m})$, are compared to better understand the microstructural evolutions under hot and superplastic forming conditions and their influence on the mechanical behavior. Hence, an accurate model with microstructural considerations is proposed. The model capabilities consider the grain size evolution that is influenced by the temperature and deformation. The computed flow stresses strongly depend on the strain rate and on the considered initial grain size. Temperature and strain rate conditions may lead to a strain hardening phenomenon in some cases. The comparison between the model response and experiment shows a good agreement for all the tests carried out on Ti-6Al-4 V.
\end{abstract}

Keywords: Superplasticity / hot forming / microstructure evolution / titanium / mechanical behavior

Die vorliegende Arbeit zielt darauf ab, das mechanische Verhalten einer Ti-6Al-4 VLegierung unter heißen und superplastischen Umformbedingungen zu bewerten und zu verstehen. Zugversuche wurden bei Temperaturen im Bereich von $650{ }^{\circ} \mathrm{C}$ bis $950{ }^{\circ} \mathrm{C}$ und Dehnungsgeschwindigkeiten zwischen $10^{-2} \mathrm{~s}^{-1}$ und $10^{-4} \mathrm{~s}^{-1}$ durchgeführt. Drei gleichachsige Mikrostrukturen, die jeweils durch eine unterschiedliche Ausgangskorngröße $(4,88 \mu \mathrm{m}, 3,0 \mu \mathrm{m}$ und $0,5 \mu \mathrm{m})$ gekennzeichnet sind, werden verglichen, um ein Verständnis der Mikrostrukturentwicklung unter warmen und superplastischen Umformbedingungen zu erhalten. Ein genaues Materialmodell mit

1 Polytechnic School of Engineering of the University of Sao Paulo, Dept. of Mechatronics \& Mechanical Systems Engineering, Av. Prof. Mello Moraes, 2231, SAO PAULO, CEP 05508-030, BRAZIL

2 Institute Clément Ader, Group Tool Materials Machining and Surface, Ecole des Mines d'Albi, Campus Jarlard, 81013 ALBI CEDEX 09, FRANCE

3 Kagawa University, Kagawa, Faculty of Engineering, Division of Advanced Materials Science, 2217-20 Hayashi-cho, Takamatsu, KAGAWA 761-0396, JAPAN
Corresponding author: G. F. Batalha, Polytechnic School of Engineering of the University of Sao Paulo, Dept. of Mechatronics \& Mechanical Systems Engineering, Av. Prof. Mello Moraes, 2231, SAO PAULO, CEP 05508-030, BRAZIL,

E-Mail: gfbatalh@usp.br 
mikrostrukturellen Überlegungen wird vorgeschlagen. Die Modellfähigkeiten berücksichtigen die Korngrößenentwicklung, die durch die Temperatur und Verformung beeinflusst wird. Die berechneten Strömungsbelastungen hängen stark von der Dehnungsrate und der betrachteten Anfangskorngröße ab. Temperatur- und Dehnungsgeschwindigkeitsbedingungen können in einigen Fällen zu einem Dehnungsverfestigungsphänomen führen. Der Vergleich zwischen Modellreaktion und Experiment zeigt eine gute Übereinstimmung für alle an Ti-6Al-4 V durchgeführten Tests.

Schlüsselwörter: Superplastizität / Warmumformung / Mikrostrukturentwicklung / Titan / mechanisches Verhalten

\section{Introduction}

During hot and superplastic forming processes, the sheet forming capabilities depend on the selected alloy (microstructural properties and chemical composition) and on the process parameters (temperature and strain rate). The Ti-6Al-4 V alloy is a typical $\alpha+\beta$ titanium alloy, wherein the element aluminum acts as an $\alpha$ phase (HC) stabilizer and the element vanadium acts as a $\beta$ phase (BCC) stabilizer [1]. The attractive properties such as high strength to weight ratio, good fatigue properties and excellent corrosion resistance, have made Ti-6Al-4 V a leading option for manufacturing aerospace and biomedical components.

The development of the superplastic forming technology significantly contributes to manufacturing titanium alloy products of high performance with low cost and short cycle. In the hot forming process of titanium alloys, temperature control is essential due to the phase transformations that may cause degradation of the mechanical properties or even the embrittlement formed in the temperature range $940-980{ }^{\circ} \mathrm{C}$ [2].

In the present work, several tensile tests performed on flat specimens in Ti-6 $\mathrm{Al}-4 \mathrm{~V}$ alloy at different temperatures and strain rates, were conducted by using a MTS hydraulic test machine. The thermo-mechanical behavior was analyzed under hot forming conditions with a temperature range from $700{ }^{\circ} \mathrm{C}$ to $950{ }^{\circ} \mathrm{C}$ and a strain rate $(\dot{\varepsilon})$ from $10^{-2} \mathrm{~s}^{-1}$ to $10^{-4} \mathrm{~s}^{-1}$. In addition, a behavior model is formulated and the constitutive parameters were identified from the previous tests [3]. It allows the prediction of both microstructural evolutions and strain-stress curves under variant temperature and strain rate conditions. The comparison with experiment are in a good agreement.

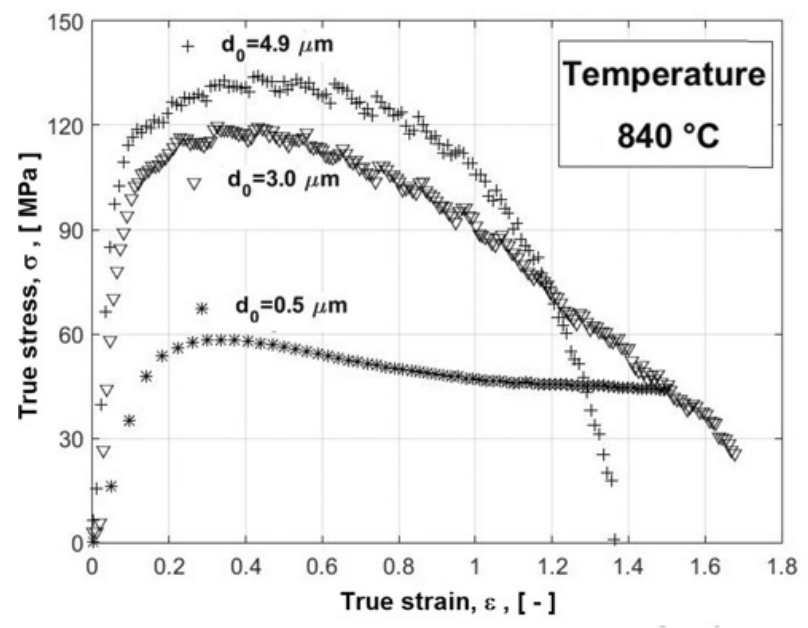

(a)

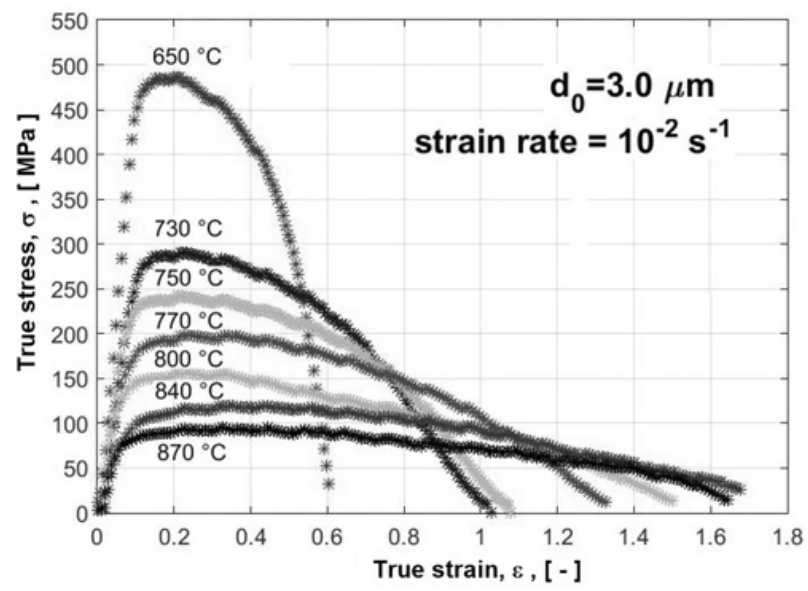

Figure 1. True stress versus true strain curves. (a) The influence of the starting microstructure and (b) the influence of the test temperature.

Bild 1. Wahre Spannung gegenüber wahrer Dehnung. (a) Einfluss der Startmikrostruktur und (b) Einfluss der Testtemperatur. 
Table 2. Dynamic test conditions, for an initial grain size of $d_{0}=\left(\# 0.5, \times 3.0,{ }^{*} 4.9 \mu \mathrm{m}\right)$.

Tabelle 2. Dynamische Versuchsbedingungen für eine anfängliche Korngröße von $d_{0}=\left(\# 0,5 \times 3,0,{ }^{\star} 4,9 \mu \mathrm{m}\right)$.

\begin{tabular}{|c|c|c|c|c|c|c|c|c|}
\hline Strain rate & $\begin{array}{l}\mathrm{T}\left({ }^{\circ} \mathrm{C}\right) \\
650\end{array}$ & 700 & 750 & 770 & 800 & 840 & 870 & 920 \\
\hline$\dot{\varepsilon}=10-2 \mathrm{~s}-1$ & *\# & *\# & *\# & $x$ & $x^{*}$ & $x^{*} \#$ & $x^{*}$ & $\times$ \\
\hline$\dot{\varepsilon}=5.10-3 \mathrm{~s}-1$ & *\# & $\#$ & *\# & & & & & \\
\hline$\dot{\varepsilon}=10-3 \mathrm{~s}-1$ & *\# & ${ }^{*} \#$ & *\# & $\times$ & $x^{*}$ & $x^{*}$ & $x$ & $\times$ \\
\hline$\dot{\varepsilon}=5.10-4 \mathrm{~s}-1$ & *\# & $\#$ & *\# & & & & & \\
\hline$\dot{\varepsilon}=10-4 \mathrm{~s}-1$ & *\# & *\# & *\# & $x$ & $x^{*}$ & $x^{*} \#$ & $x^{*}$ & $\times$ \\
\hline
\end{tabular}

\section{Hot forming and microstructural evolution model}

The mechanical behavior was investigated through the true stress versus true strain curves and considers three different equiaxed starting microstructure with initial average $\alpha$ grain sizes of $0.5 \mu \mathrm{m} ; 3.0 \mu \mathrm{m}$ and $4.9 \mu \mathrm{m}$, Figure la, b. The grain growth of Ti$6 \mathrm{Al}-4 \mathrm{~V}$ alloy was quantified by using scanning electron microscopy (SEM) observations and image analysis. Hence, the relationships between the microstructural evolution, strain rates and temperatures were analyzed. The grain boundary sliding (GBS) and grain growth play an important role in flow stress and hardening [4]. From these observations, an optimization procedure was implemented for identifying the model parameters and studying the influence of the starting microstructure and its evolution on the mechanical properties of the Ti-6Al$4 \mathrm{~V}$ alloy. Regarding our test conditions, the grain growth effect of the $\alpha$-phase was assumed to be the major mechanisms affecting the mechanical properties. This phenomenon was taken into account by using evolution equations from literature [5-7].

\section{Materials and experimental procedure}

The typical chemical composition of the Ti-6Al-4 V titanium alloy investigated in the present work is referred to typical $\alpha+\beta$ titanium alloy, Table 1 .

The mechanical tensile tests were performed by using a servo-hydraulic testing machine and a furnace suitable and accurate for the very large elongations. It includes three heating zones controlled by five thermocouples and allows maintaining a constant temperature all along the sample deformation.
Table 1. General chemical composition wt.\%.

Tabelle 1. Chemische Zusammensetzung in Gew\%.

\begin{tabular}{lllll}
\hline Al & V & O & $\mathrm{N}$ & $\mathrm{Ti}$ \\
\hline 6.50 & 4.24 & 0.17 & 0.004 & Bal. \\
\hline
\end{tabular}

As the use of a classical extensometer was not possible due to the very large elongation, a nonlinear crosshead displacement was considered for all the mechanical tests to obtain a constant target strain rate $\dot{\varepsilon}$ at the center of the specimen. Thus, the time variation of applied displacement $u(t)$ was provided by Equation 1. Afterwards, the true strain $\varepsilon_{t}$ and the true stress $\sigma_{t}$ evolutions were computed from the displacement value $u(t)$ given by the previous equation (Equations 2, 3).

$u(t)=l_{0}\left(e^{\dot{\varepsilon} t}-1\right)$

where $l_{0}$ is the initial gauge length; $\dot{\varepsilon}$ is the target strain; $t$ is the time

$\varepsilon_{t}=\log \left(1+\frac{u(t)}{I_{0}}\right)$

$\sigma_{t}=\frac{\mathrm{F}}{S_{0}}\left(1+\frac{u(t)}{I_{0}}\right)$

where $F$ is the strength registered by the load sensor of the equipment and $S_{0}$ the initial section of the specimen. Depending on the microstructure, some of the mechanical tests were performed at the Institute Clément Ader (France), while other ones were conducted at the Kagawa University (Japan). The capabilities of each equipment are similar; the main difference concerns the sample shape and the gauge length to be considered in the strain calculation. 

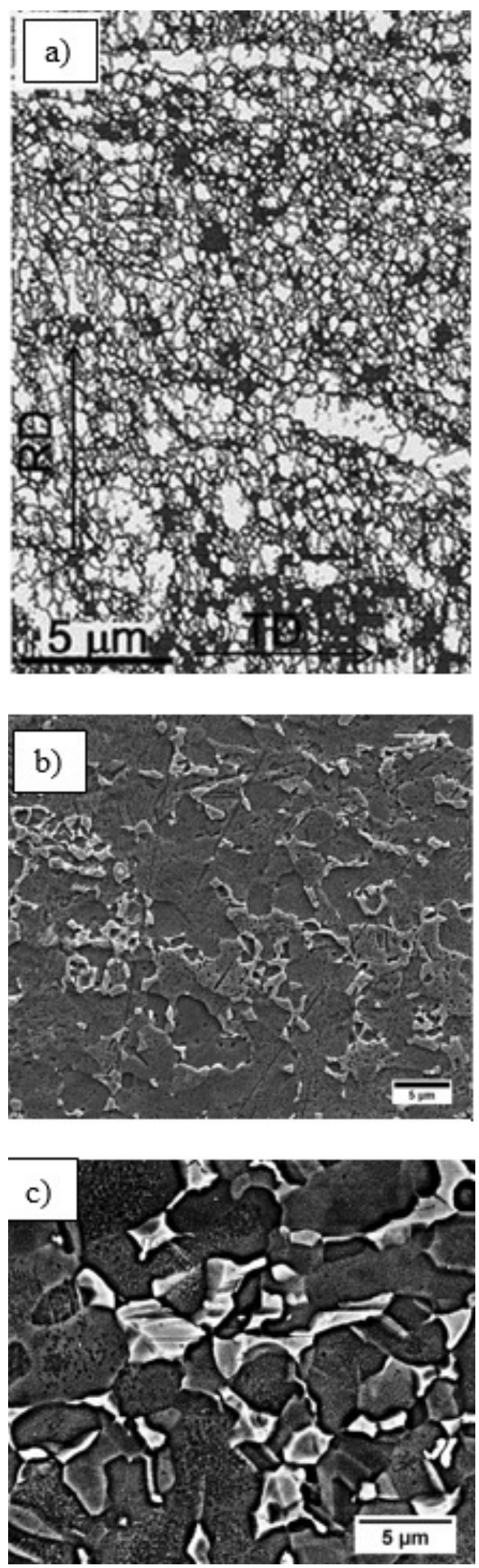

Figure 2. Grain size starting microstructure: ultrafine grained (a); $3.0 \mu \mathrm{m}$ and (b) and $4.9 \mu \mathrm{m}$ (c).

Bild 2. Korngröße der Startmikrostruktur: ultrafeinkörnig (a) $3,0 \mu \mathrm{m}$, (b) und $4,9 \mu \mathrm{m}$ (c).

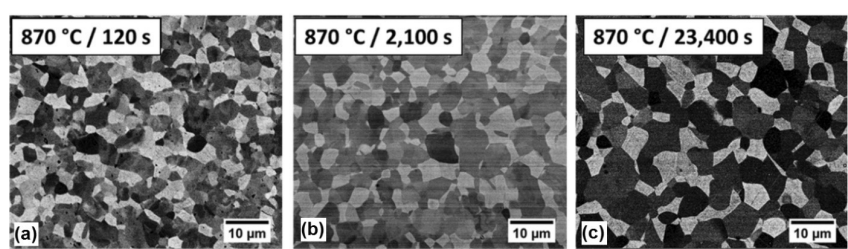

Figure 3. Static tests: Grain coarsening evolution for different times at $870{ }^{\circ} \mathrm{C}$. (a) $120 \mathrm{~s}$, (b) $2,100 \mathrm{~s}$ and (c) $23,400 \mathrm{~s}$.

Bild 3. Statische Tests: Entwicklung der Kornvergröberung für verschiedene Zeiten bei $870^{\circ} \mathrm{C}$. (a) $120 \mathrm{~s}$, (b) $2.100 \mathrm{~s}$ und (c) $23.400 \mathrm{~s}$.

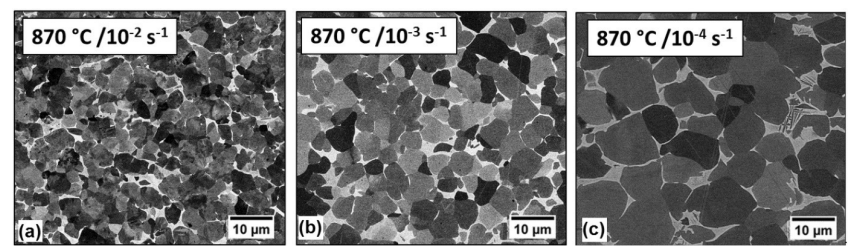

Figure 4. Dynamic test coarsening evolution grain at $870{ }^{\circ} \mathrm{C}$ for different strain rates. (a) $10^{-2} \mathrm{~s}^{-1}$, (b) $10^{-3} \mathrm{~s}^{-1}$ and (c) $10^{-4} \mathrm{~s}^{-1}$. Bild 4. Entwicklung der Kornvergröberung bei dynamischen Tests für verschiedene Dehnraten bei $870{ }^{\circ} \mathrm{C}$. (a) $10^{-2} \mathrm{~s}^{-1}$, (b) $10^{-3} \mathrm{~s}^{-1}$ und (c) $10^{-4} \mathrm{~s}^{-1}$.

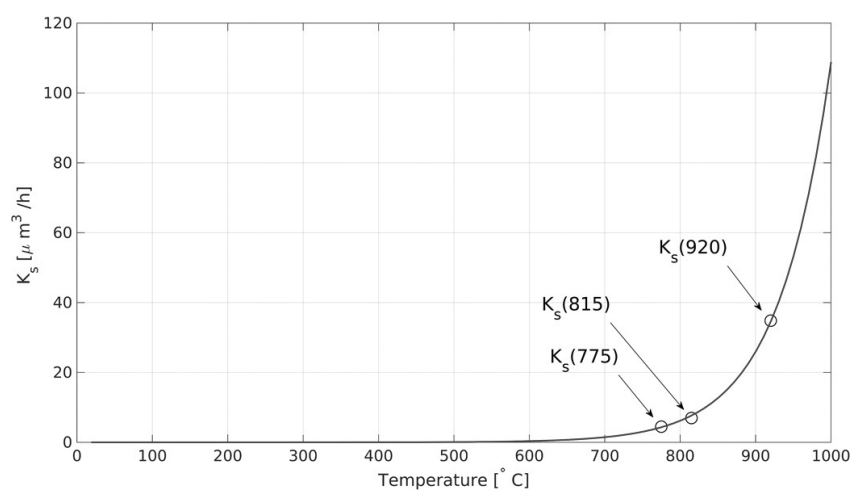

Figure 5. Grain growth prediction under static conditions.

Bild 5. Prognose des Kornwachstums unter statischen Bedingungen.

\section{Microstructural characterization}

\subsection{Procedure}

Three different equiaxed $\alpha$ grain starting microstructures were compared and the mechanical tests (dynamic tests) performed at different temperatures, strain rates and starting microstructures, Table 2. In addition, several annealing tests (static tests) were added under the same time-temperature conditions to investigate 

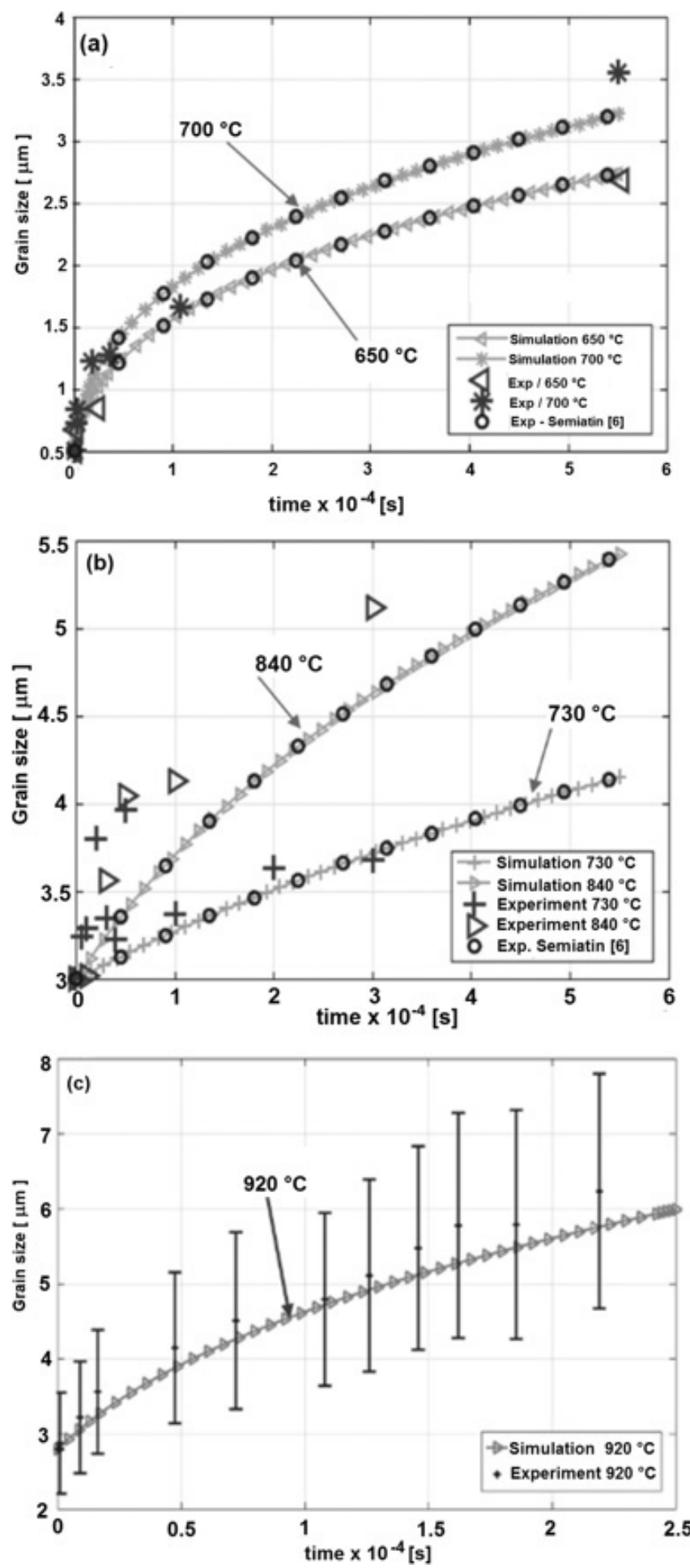

Figure 6. Comparisons between model predictions and experimental measurements. (a) $650^{\circ} \mathrm{C}$ and $700{ }^{\circ} \mathrm{C}$, (b) $730{ }^{\circ} \mathrm{C}$ and $8400^{\circ} \mathrm{C}$ (c) $920^{\circ} \mathrm{C}$.

Bild 6. Vergleich der Modellprognose und Messungen. (a) $650{ }^{\circ} \mathrm{C}$ und $700^{\circ} \mathrm{C}$, (b) $730^{\circ} \mathrm{C}$ und $840^{\circ} \mathrm{C}$ und (c) $920^{\circ} \mathrm{C}$. the temperature and straining effects separately from each other. The eight levels of temperatures ranging from $700{ }^{\circ} \mathrm{C}$ to $920^{\circ} \mathrm{C}$ and the five different strain rates ranging from $10^{-4} \mathrm{~s}^{-1}$ to $10^{-2} \mathrm{~s}^{-1}$ were considered.

For each test condition, a microstructural investigation was conducted using scanning electron microscopy observations. This allows comparing the starting microstructure and its evolution over time, temperature and deformation.

Three different microstructures were compared: the first one, designed as ultrafine-grained microstructure (UFGM), was obtained by using a combined "forging-rolling" process providing plates with thicknesses from $1.4 \mathrm{~mm}$ to $1 \mathrm{~mm}$ and an average grain size of $0.5 \mu \mathrm{m}$, Figure 2a [8]. A second and a third starting microstructure (SM), belongs to the most widely used starting microstructure (SM) for superplastic forming (SPF), Figure 2b, c. It considers an equiaxed $(\alpha+\beta)$ Ti-6Al-4 V alloy with an average $\alpha$ phase grain size equal to $3 \mu \mathrm{m}$ and $4.9 \mu \mathrm{m}$, respectively $[9,10]$.

As mentioned before, grain growth was investigated by conducting static and dynamic tests. The static tests were carried out at several temperatures and for different exposure times like those considered during the dynamic tests. A grain growth evolution was noted during the static tests done at the temperature $870{ }^{\circ} \mathrm{C}$ and the several exposure times 120 s, 2,100 s and 23,400 s, Figure 3.

A grain growth evolution was also observed for the case of the dynamic tests carried out at the temperature $870{ }^{\circ} \mathrm{C}$ under different strain rates: $\dot{\varepsilon}=10^{-2} \mathrm{~s}^{-1}$, $\dot{\varepsilon}=10^{-3} \mathrm{~s}^{-1}$ and $\dot{\varepsilon}=10^{-4} \mathrm{~s}^{-1}$, Figure 4 .

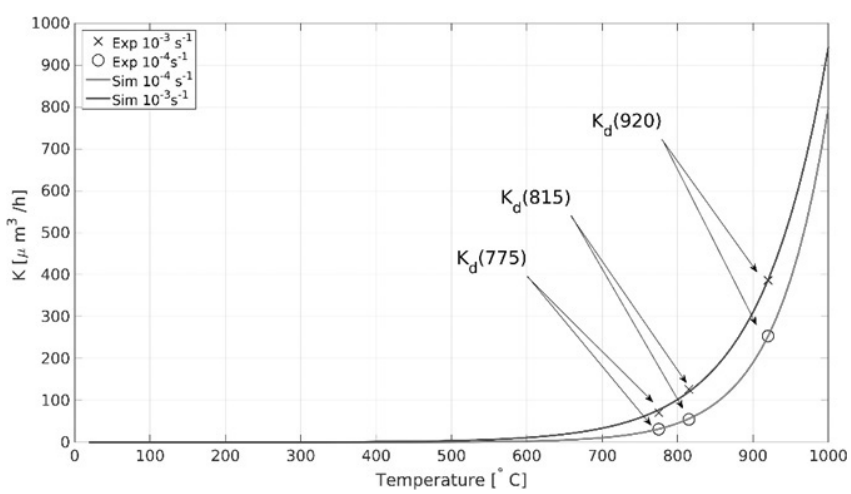

Figure 7. Grain growth prediction under dynamic conditions.

Bild 7. Prognose des Kornwachstums unter dynamischen Bedingungen. 

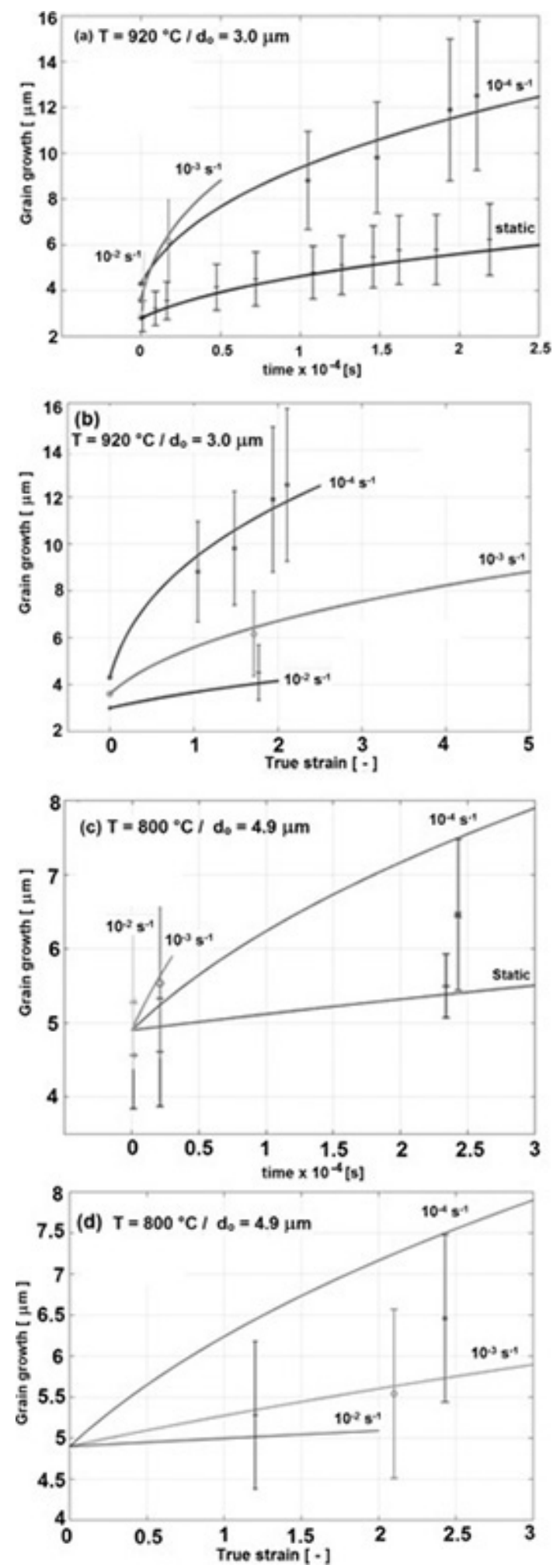

Figure 8. The dynamic grain growth (Eq. 7) allows reproducing grain growth kinetics over a range of temperatures and strain rates.

Bild 8. Das dynamische Kornwachstum (Gleichung 7) ermöglicht die Reproduktion der Kornwachstumskinetik über einen Bereich von Temperaturen und Dehnungsraten.
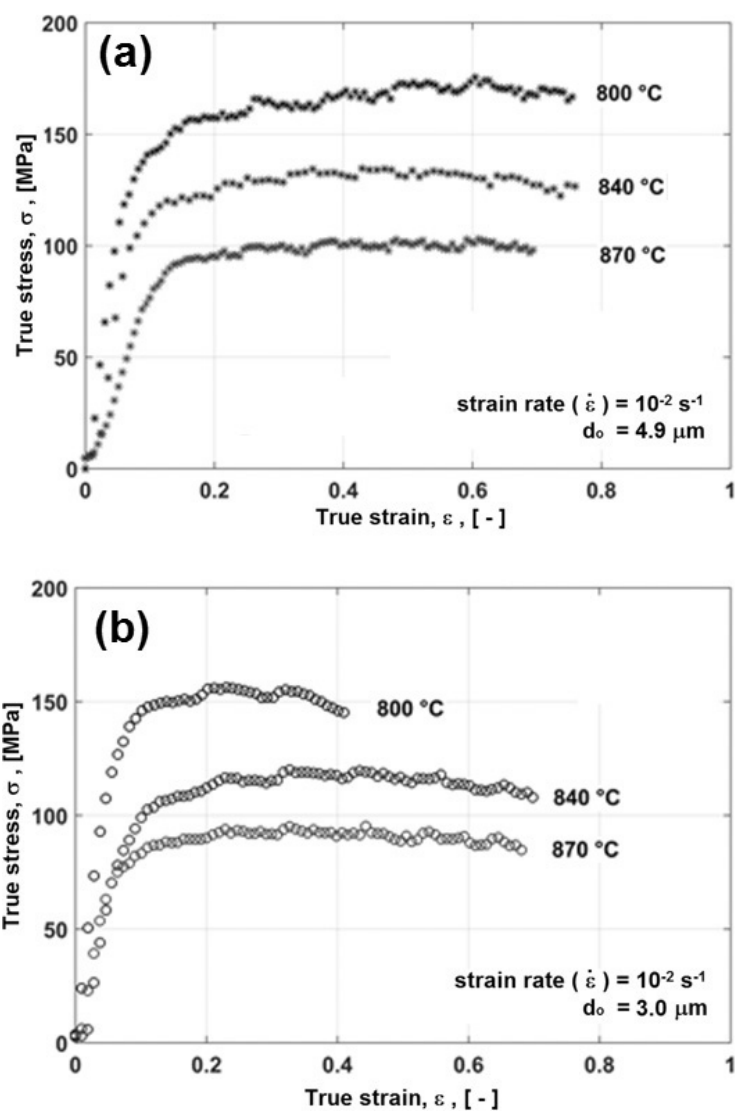

Figure 9. Comparison between the computed true strain true stress curves for two starting grain sizes: (a) $4.9 \mu \mathrm{m}$ and (b) $3.0 \mu \mathrm{m}$ testes at the temperatures 800,840 and $870{ }^{\circ} \mathrm{C}$.

Bild 9. Vergleich der berechneten wahren Spannungs- wahren Dehnungskurven für zwei verschiedene Start-Korngrößen: (a) 4,9 $\mu \mathrm{m}$ und (b) 3,0 $\mu \mathrm{m}$ getestet bei den Temperaturen 800,840 und $870{ }^{\circ} \mathrm{C}$.

\subsection{Grain growth predictions under static conditions}

The grain growth will be defined as an internal variable of the behavior model. In this section, the grain growth evolution model is described in Equation 4 [4]. The identification procedure is based on both present experiments and results given by the Semiatin's empirical law given in Equation 5, where the static coefficient $\left(K_{\mathrm{s}}\right)$ was determined at different temperature levels, allowing its interpolation with a more important temperature range [5,6], Figure 5. 

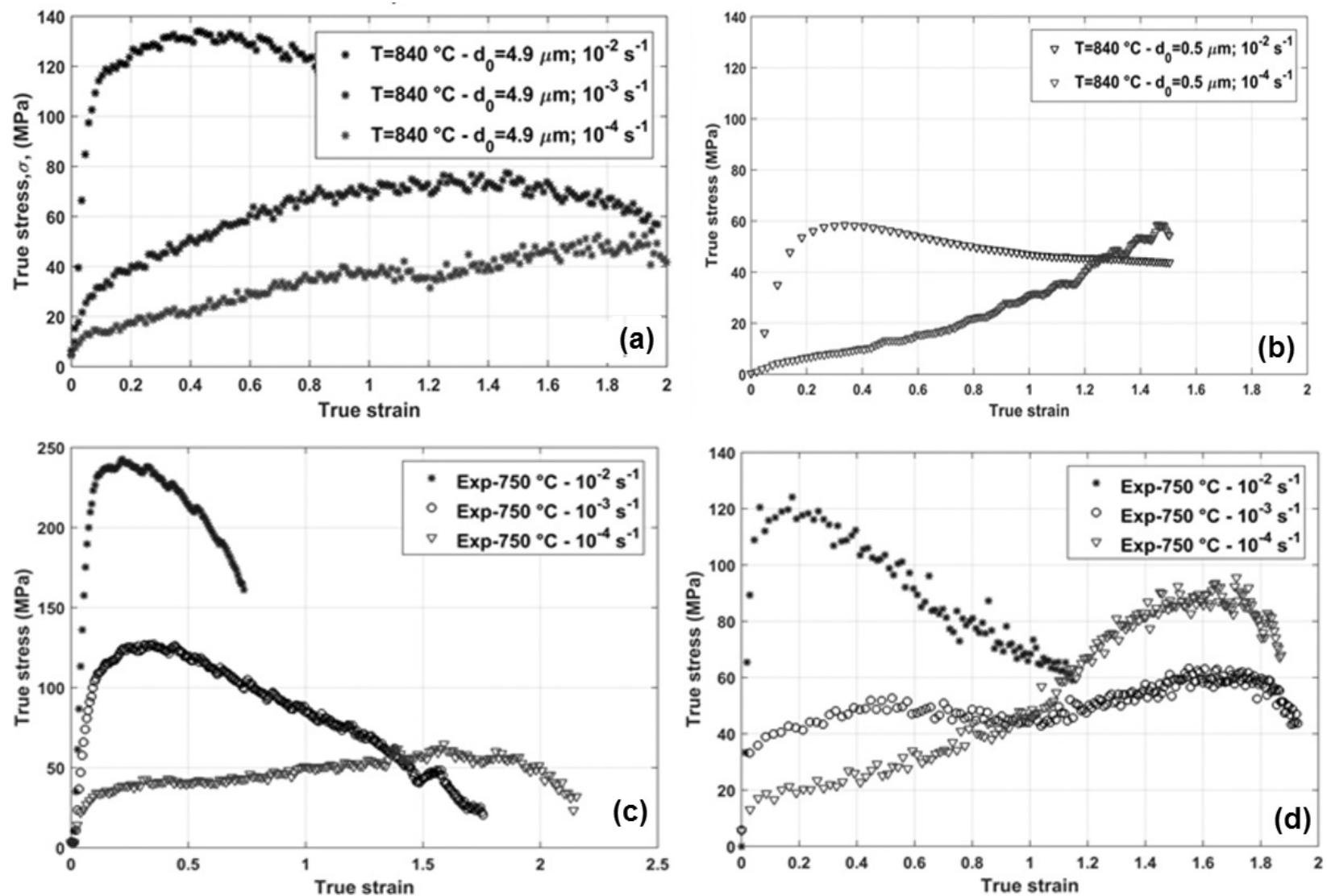

Figure 10. The effect of start grain size on stress-strain response: (a) $4.9 \mu \mathrm{m}$ at $840{ }^{\circ} \mathrm{C}$, (b) $0.5 \mu \mathrm{m}$ at $840{ }^{\circ} \mathrm{C}$, (c) $3.0 \mu \mathrm{m}$ at $750{ }^{\circ} \mathrm{C}(\mathrm{d})$ and $0.5 \mu \mathrm{m}$ at $750{ }^{\circ} \mathrm{C}$ for different strain rates.

Bild 10. Effekt der Start-Korngröße auf Spannungs-Dehnungs-Antwort: (a) $4,9 \mu \mathrm{m}$ bei $840{ }^{\circ} \mathrm{C}$, (b) $0,5 \mu \mathrm{m}$ bei $840{ }^{\circ} \mathrm{C}$, (c) $3,0 \mu \mathrm{m}$ bei $750{ }^{\circ} \mathrm{C}$ und (d) $0,5 \mu \mathrm{m}$ bei $750{ }^{\circ} \mathrm{C}$ für verschiedene Dehnraten.

Table 3. Unified constitutive equations.

Tabelle 3. Einheitliche konstitutive Gleichungen.

$\dot{d}_{s}$ Atomic diffusion grain boundary mobility $\dot{d}_{d}$ grain growth kinetics

$A_{\mathrm{i}}, m_{\mathrm{i}}$ and $n_{\mathrm{i}}$ are temperature parameters

$p$ - effective inelastic strain

$\dot{d}=\dot{d}_{s}+\dot{d}_{d}$

Yield criterion

$\dot{d}_{s}=A_{1} d^{-m_{1}}$

$\dot{d}_{d}=A_{2} d^{-m_{2}} \dot{p}^{n_{1}}$

Isotropic hardening variable:

$f=\sigma_{e q}-R-\sigma_{0}$

Influence on the hardening

$=>\sigma_{e q}=\sqrt{\frac{3}{2} S: S}$

$R=Q\left(1-e^{-b p}\right)$

$Q=Q_{0} e^{\gamma \Delta d}$

Associated strain rule

$\Delta d=d-d_{0}$

Influence on the viscous flow:

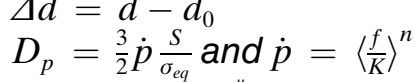

$K=K_{r}\left(\frac{d}{\chi\left(d_{0}\right)}\right)^{\frac{\mu}{n}}$;

Corotational stress rate

$n=n_{r}\left(\frac{d}{\chi\left(d_{0}\right)}\right)^{\alpha} ; \chi\left(d_{0}\right)=\chi_{1} e^{-\chi_{0} d_{0}} ;$

$\stackrel{\nabla}{\sigma}=2 G D_{e}+\lambda \operatorname{Tr}\left(D_{e}\right)$

Strain rate partition

$D_{e}=D_{t}-D_{p}$ 

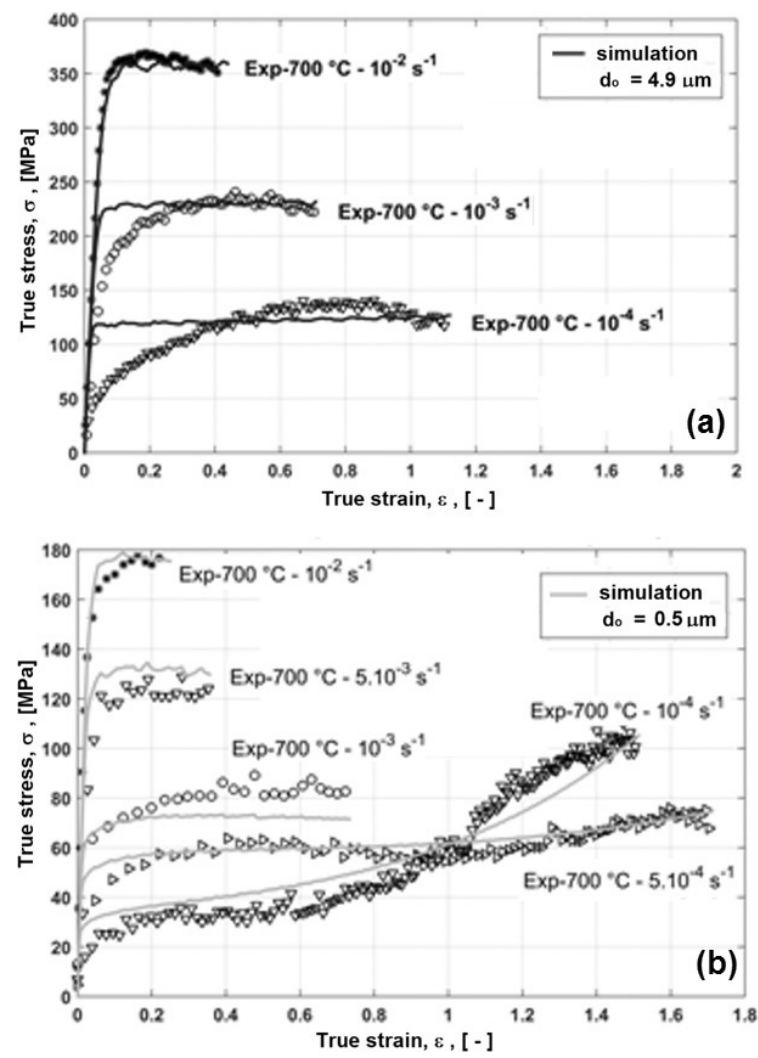

Figure 11. Computed strain-stress data versus experimental results at a temperature of $700{ }^{\circ} \mathrm{C}$ and initial grain size of (a) $0.5 \mu \mathrm{m}$ and (b) $4.9 \mu \mathrm{m}$.

Bild 11. Berechnete Dehnungs-Spannungsdaten und experimentelle Ergebnisse bei einer Temperatur von $700^{\circ} \mathrm{C}$ und Start-Korngrößen von (a) 0,5 $\mu \mathrm{m}$ und (b) $4,9 \mu \mathrm{m}$.

$\dot{d}_{s}=A_{1} d^{-m_{1}}$

$d^{3}(t)-d_{0}^{3}=K_{s}(T) . t$

where $A_{1}$ and $m_{1}$ depend on temperature $(T)$

Computed grain growth-time and computed grain growth-strain curves were compared using the evolution law identified with the coarsening rate constants and the experimental measurements performed under temperatures ranging from $700{ }^{\circ} \mathrm{C}$ to $920{ }^{\circ} \mathrm{C}$ and an initial grain size: $d_{0}=3 \mu \mathrm{m}$, Figure 6 [6].

\subsection{Grain growth predictions under dynamic conditions}

Similarly to the previous paragraph, dynamic grain growth was investigated by using the Semiatin's empirical law given in Equation 6 and the measure- ments performed in the present study from secondary electron microscopy image analysis $[5,6]$. The enhanced Semiatin's law modelling allows for a simulation into a wide temperature range, Figure 7. Hence, the parameters of Equation 7 governing the dynamic grain growth are identified.

$d^{3}(t)-d_{0}^{3}=K_{d}(T) \cdot t$

$\dot{d}_{d}=A_{2} d^{-m_{2}} \dot{p}^{n_{1}}$

The simulation allowed a comparison of the computed grain growth-time and the computed grain growth-strain curves, using the evolution law identified with the coarsening rate constants by Semiatin and coworkers and the experimental measurements performed at the temperature of $920{ }^{\circ} \mathrm{C}$ and an initial grain size $d_{0}=3 \mu \mathrm{m}$; as well as for the temperature of $800{ }^{\circ} \mathrm{C}$ and an initial grain size $d_{0}=4.9 \mu \mathrm{m}$, Figure 8 [6].

\section{Mechanical characterization}

\subsection{Experiment}

The stress-strain response was investigated for $4.9 \mu \mathrm{m}$ and $3.0 \mu \mathrm{m}$ grain size microstructures and temperatures ranging from $800{ }^{\circ} \mathrm{C}$ to $870{ }^{\circ} \mathrm{C}$. It illustrates a behavior with a significant strain rate sensitivity, Figure 9.

It was compared the strain-stress curves obtained at the temperatures $750{ }^{\circ} \mathrm{C}$ and $870{ }^{\circ} \mathrm{C}$ for two starting microstructures $\left(d_{0}=0.5 \mu \mathrm{m}\right.$ and $\left.d_{0}=4.9 \mu \mathrm{m}\right)$. In each case, strain rates ranging from $10^{-4} \mathrm{~s}^{-1}$ to $10^{-2} \mathrm{~s}^{-1}$ are considered. The ultra-fine grain (UFG) microstructure eases a grain boundary sliding (GBS) mechanism. Therefore, it induces lower flow stresses and more important elongations compared to the starting microstructure of $4.9 \mu \mathrm{m}$. For some test conditions, (lower strain rates) a strain hardening effect is observed mainly due to grain growth. A slight stress increase occurs for the starting microstructure of $4.9 \mathrm{~mm}$ at $750{ }^{\circ} \mathrm{C}$ and $870{ }^{\circ} \mathrm{C}$ and for a strain rate of $10^{-4} \mathrm{~s}^{-1}$. However, it becomes more significant for the ultrafine grain (UFG) microstructure corresponding to a more important grain growth, Figure 10. 

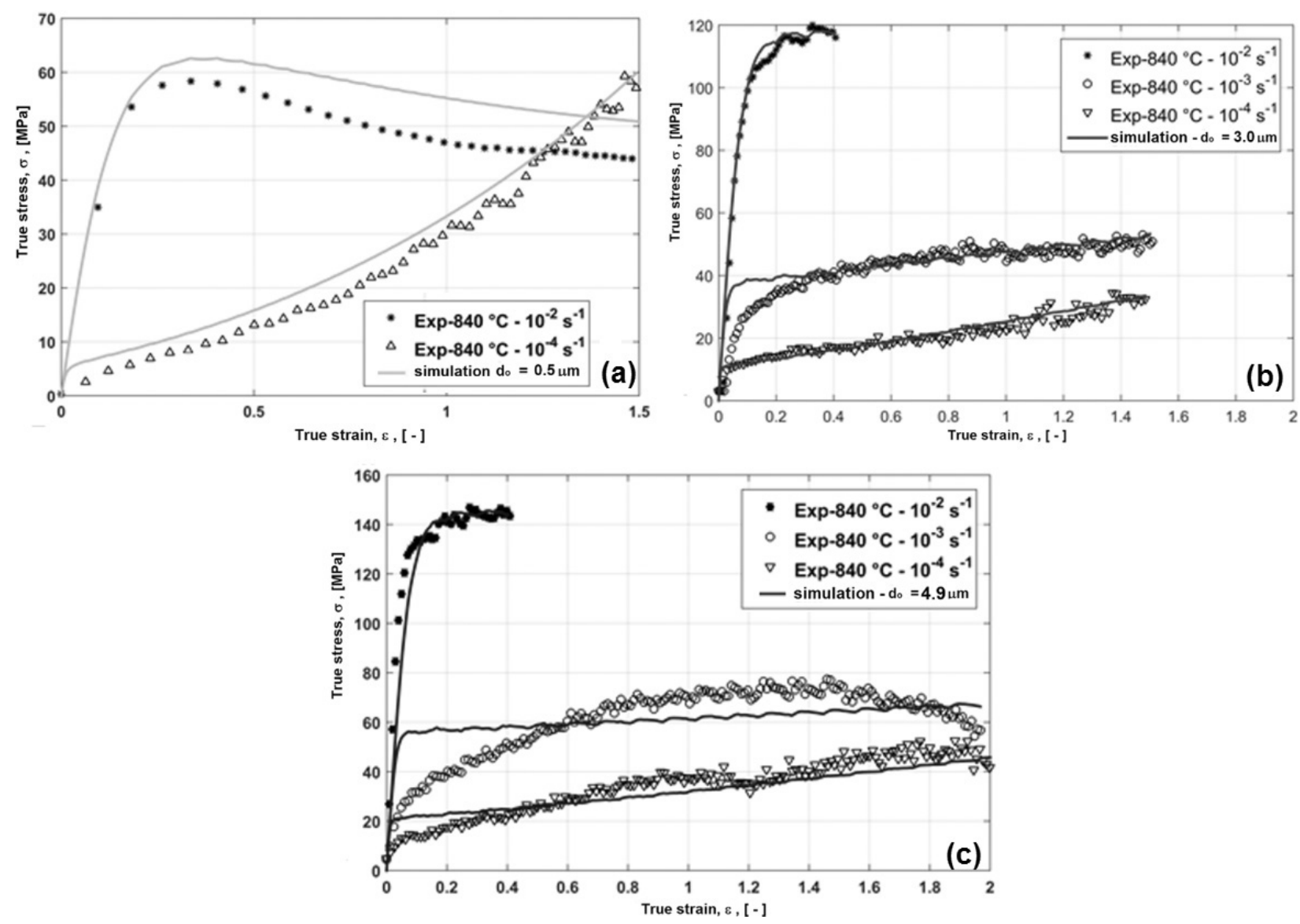

Figure 12. Computed strain-stress data versus experimental results at (a) temperature of $840{ }^{\circ} \mathrm{C}$ and initial grain size of $d_{0}=0.5 \mu \mathrm{m}$, (b) temperature of $840^{\circ} \mathrm{C}$ and initial grain size of $d_{0}=3.0 \mu \mathrm{m}$ and (c) temperature of $840{ }^{\circ} \mathrm{C}$ and initial grain size of $d_{0}=4.9 \mu \mathrm{m}$.

Bild 12. Berechnete Dehnungs-Spannungsdaten und experimentelle Ergebnisse bei (a) $840{ }^{\circ} \mathrm{C}$ und $0,5 \mu \mathrm{m}$, (b) $840{ }^{\circ} \mathrm{C}$ und $3,0 \mu \mathrm{m}$ und (c) $840^{\circ} \mathrm{C}$ und $4,9 \mu \mathrm{m}$.

\subsection{Behavior modelling}

This part deals with the constitutive equations able to reproduce the thermomechanical strain-stress response of Ti-6Al-4 V titanium alloy under hot and superplastic forming conditions. The behavior model is introduced in detail [10]. The constitutive equations represent the proposed approach and can consider, Table 3:

- the strain rate sensitivity

- the temperature effect

- variant starting microstructures and their evolutions over time, temperature and deformation

- when occurring, strain hardening effect eased for the ultra-fine grain (UFG) microstructure and low strain rates

The identification of the model parameters is described in detail where the model gives prediction in a good agreement with experiment for two starting microstructures [10]. In the present study, the model predictions are extended to the starting microstructure of $4.9 \mu \mathrm{m}$.

At $700{ }^{\circ} \mathrm{C}$, it was not identified a deformation mechanism change for the initial grain size of $d_{0}=4.9 \mu \mathrm{m}$, whereas, this effect is observed and well assessed at lower strain rate $\left(10^{-4} \mathrm{~s}^{-1}\right)$ for an initial grain size of $d_{0}=0.5 \mu \mathrm{m}$, Figure 11 .

In the case of the starting microstructure of $0.5 \mu \mathrm{m}$, the behavior model predicts a stress decrease under certain conditions at $10^{-2} \mathrm{~s}^{-1}$, Figure 12. This is due to a non-constant strain rate applied during the test, inducing a slight strain rate decrease with the sample elongation.

Whatever the test conditions and the starting microstructure considered, the model responses pro- 
vide a good prediction of the whole experimental database.

\section{Conclusions}

The superplastic behavior of a Ti-6Al-4 V Titanium alloy was investigated under hot forming conditions regarding three different starting microstructures with an average $\alpha$ grain size of $0.5,3$ and $4.9 \mu \mathrm{m}$. A temperature range from $700{ }^{\circ} \mathrm{C}$ to $920{ }^{\circ} \mathrm{C}$ and different strain rates between $10^{-4} \mathrm{~s}^{-1}$ and $10^{-2} \mathrm{~s}^{-1}$ were considered.

The parameters of a grain growth model are identified and the measurements performed successfully describe the predicted evolutions [6].

The internal variable related to grain growth was introduced into the mechanical model through the viscous flow and the hardening variable.

The following results can be drawn:

- the strain-stress response exhibits a viscous flow dependent on the test temperature, the initial microstructure and the grain growth

- a strain hardening is observed for the initial-period of the test due to the grain growth evolution.

- the viscous flow was dependent on the initial microstructure and its evolution

- the strain hardening was observed during the beginning of the test due to the grain growth evolution.

At the higher temperatures $\left(\mathrm{T}>900{ }^{\circ} \mathrm{C}\right)$ the model formulation must be improved by adding a new mechanism related to the $\beta$ phase whose effect becomes predominant.

\section{Acknowledgements}

Marcio Wagner B. Santos acknowledges his ongoing scholarship and the financial support from the Brazilian Federal Agency for Support and Evaluation of Graduate Education - CAPES (Coordination for the Improvement of Higher Education Personnel).

\section{References}

[1] E. Alabort, D. Putman, R.C. Reed, Acta Mater. 2015, 95, 428.

[2] C. Nicolas, DSA dissertation, Ecole Polytechnique de Louvain, University Catholique de Louvain, Belgium, 2010.

[3] J. Bonet, A. Gil, R.D. Wood, R. Said, R.V. Curtis, Comput. Methods Appl. Mech. Eng. 2006, 195, 6580.

[4] J. Lin, T. Zhu, L. Zhan, Superplastic Forming of Advanced Metallic Materials. Elsevier, Oxford, 2011.

[5] S.L. Semiatin, P.N. Fagin, J.F. Betten, A.P. Zane, A.K. Ghosh, G.A. Sargent, Metall. Mater. Trans. A 2010, 41, 499.

[6] S.L. Semiatin, G.A. Sargent, Key Eng. Mater. 2010, 433, 235.

[7] S. Bruschi, T. Altan, D. Banabic, P.F. Bariani, A. Brosius, J. Cao, A. Ghiotti, M. Khraisheh, M. Merklein, A.E. Tekkaya, CIRP Ann. Manuf. Technol. 2014, 63, 727.

[8] H. Matsumoto, V. Velay, A. Chiba, J. Mater. B. 2015, 66, 611.

[9] M. Santos, V. Velay, G. Bernhart, M. Stipkovic Filho, G.F. Batalha, presented at Advances in Materials and Processing Technologies AMPT - Madrid - Spain, December 14th 17th 2015, pp. 103.

[10] V. Velay, H. Matsumoto, V. Vidal, A. Chiba, Int. J. Mech. Sci. 2016, 108, 1.

[11] D.C. Chen, W.J. Chen, J.Y. Lin, International Journal of Simulation Modelling 2010, 9, 17. 